\title{
Intertwining Tongues : Bilingualism and Hybrid Texts in Contemporary Japanese Literature \\ From I am a Cat to I Become a Cat
}

Faye Yuan Kleeman

⿶faye.kleeman@colorado.edu

The study of Japanophone literature (Nihongo bungaku) has recently emerged as a new area within Japanese literary studies. Scholars consider the category as part of the legacy of Japan's colonial language policy and often focus on its subversive and productive possibilities in revealing the asymmetrical dynamics of languages and facilitating the expansion of the scope of Japanese literature. One of the features of Nihongo bungaku is its bilingual textual elements and the authors' bifocal cultural rendering of the text. This article builds on the notion that all translated texts are hybrid texts (Schaffner and Adab, 2001) and seeks to explore the potential for Japanese writers to participate in the production of Nihongo bungaku, in particular in the milieu of Sino-Japanese literary interactions. It first considers issues of bilingualism and diglossia and the historical kanji-kana graphic interface, asking whether the mixed graphic system fits into a scheme of (non) translation. Finally, the paper discusses the recent bilingual novel I Became a Cat by Yokoyama Yūta to examine his use of lexical innovation, textual hybridity, and parody. I seek to demonstrate that Yokoyama's playful gestures toward translation, transliteration, and bilingual and translingual praxis relocate Sōseki's canonical work out of the Meiji domestic environment and turn it into a bi-cultural global text.

Keywords Japanophone(日本語), Translingual practice(言語横断的実践), Kanji

sphere(漢字圈), Phonetic interface(音声のインタフェース), Hybrid texts(混種テキスト) 


\section{Introduction: Translingual Practice in bilingual, hybrid texts}

It is now a well-accepted fact that, through its colonial enterprise in the first part of the twentieth century, modern Japanese literature was infused with a new set of multilingual and multicultural characteristics. Although this textual heterogeneity faded in the long postwar era, it has recently been reclaimed to a certain degree. With productive contemporary writers such as Tawada Yōko and Hideo Levy, the study of Japanophone literature (Nihongo bungaku) has emerged as a new area within Japanese literary studies. The emerging creative tide of Nihongo bungaku is further validated by the recognition of the Chinese-born writer Yang Yi, who received the Akutagawa Award in 2008, as the first non-native writer of Japanese who ever received the award. Less than a decade later, the 2017 Yomiuri Literary Award further affirmed that the phenomenon is not just a passing fad, but has staying power. Two of the award's six awardees, Levy Hideo (fiction) and Jeffrey Angles (poetry), are foreign-born Japanese language authors. The diversity of the Yomiuri Literary Award demonstrates the continuing growth of this subcategory of literature and its evolving status to be recognized as a part of mainstream contemporary literature.

What marks this new body of literary production is that it expands the conventional definition of Japanese literature and creates a space where not only non-native Japanese writers can exercise their creative urges within the Japanese language, it also now provides a fertile ground for Japanese writers to experiment with their own language when it comes to writing fiction. The cross-fertilization of this bi-directional translingual (and transcultural) praxis will, I believe, usher in a revised conceptualization of what constitutes "Japanese" literature and provide a new and inventive contour of fiction. The discussions of Nihongo bungaku tend to hane a unidirectional focus on non-native writers who operate in the realm of Japanese language. This is true in the study of Japanese colonial literature but also true in the contemporary literary domain where the effort and hardship of committing and conforming to a different language are highlighted. Less explored are writers on a reverse trajectory of this cross-lingual and cross-cultural process.

In this article, I explore the possibility and potential Nihongo bungaku has for native Japanese writers seeking to renew their own creative drive as well as the national language. In particular, I will look at Yokoyama Yūda's 2014 novel I Become a Cat (Wagahai wa Neko ni Naru, 吾輩は猫になる) to show how a 
strategically creative bilingual fiction gave birth to a hybrid text that addresses the variability and adaptability of the shared heritage of Sino-Japanese cultural and linguistic meanings. In a sense, Yokoyama's text is a playful experimentation with how far a bilingual text can gain currency within the confines of contemporary Japanese literature. The bilingual text also reveals the productiveness of the shared similarity of the orthographic apparatus (here mainly referring to the system of Chinese kanji characters) while at the same time exposing the limitations of such a mutually distributed, symbiotic system. In other words, Yokoyama addresses the uneven and at times bumpy cultural transactions beneath the smooth surface of a shared Kanji sphere (漢字圈) and subsequently demystifies the long existent idea of ethno-cultural homogeneity (i.e. same language same race [between Chinese and Japanese] 同文同種) of the two cultures.

Bilingualism, when discussed in the context of contemporary Japan, tends to be framed as a pedagogical and education policy issue, an approach in Japan's attempt to counter encroaching globalism and English imperialism. The postwar essentialist conviction of ethno-linguistic homogeneity and isomorphism (that land $=$ people $=$ society =polity) debunked by academia (and business in recent years) in general still has a firm grip on politicians, bureaucrats, and policymakers. The discussion of installing English as second common language (第二共通語) at the turn of the millennium encountered strong opposition and was never realized. ${ }^{1}$ As a national language policy, bilingualism was not welcomed and in the realm of literary production, bilingualism is not something discussed in a monolingual creative environment. For this reason, when Mizumura Minae's novel titled Shishōsetsu from left to right (1995) was published, it garnered a lot of critical attention and was touted as "the first bilingual novel" in Japan. Moved to the US at age twelve due to her father's work, Mizumura grew up in wealthy Long Island suburb and received a doctoral degree in French literature from Yale. But she decided to return to Japan to become a writer so she could use her own chosen language, Japanese, as her creative language. Her debut novel Meian---continued (Zoku meian 続明暗 1990) sought to finish the greatest Japanese modern writer Natsume Sōseki's unfinished last work, Meian (Light and Darkness, 1916). This was a truly daring act

\footnotetext{
1 In 2000, then prime minister Ōbuchi Keizō proposed as part of his Framework for 21st Century Japan that English be designated as the second common language for Japan. The proposal encountered opposition, some from the conservatives who worried it would take time away from studying Japanese; some opposed not the designation of a common second language but objected to English as the appropriate one. See Suzuki Yoshi 鈴木義里『論争·英語が公用語になる日』(中央公論社, 2002).
} 
for an unknown writer in a canon-bound society. Her second novel also challenged the definitive place of the I-novel (shisōsetsu) as a narrative mode in Japan. The novel's protagonist Minae (same as the name of the author) relates her life in America through a series of long telephone conversations with her sister Nanae in English while the rest of the narrative is in Japanese. This parallel bilingual text perhaps is what comes closest to the standard definition of a bilingual work of fiction. Yet, part of its intended readership, who are not particularly proficient in English (those with only a high school degree), may not, fully comprehend all the nuances of the work without translation, thus making this particular text exclusively for some elite readers. Notice that the text can still maintain its dualistic structure if translated into any other language other than English. However, the author Muzumura's strategic employment of Japanese/English bilingualism of the text makes this masterpiece ineffectual when translated into English since the bilingual visual juxtaposition of the two languages would be absent. To this day, although readers in the English language can read Mizumura's other works such as $A$ True Novel (Honkaku shōsetsu, English translation 2014) or Inheritance from Mother (Haha no isan, English translation 2017), they still have no access to this very important work.

As Lydia Liu pointed out in her "The Problem of Language in Cross-Cultural Studies," in order to cross the "language barrier" between two or more cultural and linguistic communities, we must often rely on translation to facilitate the epistemological transaction. ${ }^{2}$ This epistemological transaction exchanges one language for another, according to the translation theorists Christina Schaffner and Beverly Adab, making all translated texts into "hybrid texts." In their definition, a hybrid text is "a text that results from a translation process." It shows features that somehow seem 'out of place,' 'strange' 'unusual' for the receiving culture (i.e., the target culture). ${ }^{3}$ Hybrid texts (or the French concept of métissage) are defined as those texts which use "translation effects" to question the borders of identity. In other words, hybrid texts are produced by writers who want to highlight their position between cultures, creating a new site of individual and collective expression. It has the potential to open up a third space between totality (fusion,

2 Lydia H Liu, Translingual Practice Literature, National Culture, and Translated Modernity-China, 19001937. (California: Stanford University Press, 1995): 1-42.

3 Christina Schäffner and Beverly Adab, "The Idea of the Hybrid Text in Translation: Contact as Conflict." Across Languages and Cultures Vol.2, No.2 (2001): 167-180. 
homogeniety) and differentialism (fragmentation, heterogeneity), and make visible the tension between them, as in a hybrid composition the components are still visible.

While bilingualism has ties to personal choice, speaker's experience, and the process of language acquisition and the formation of linguistic identity, diglossia denotes a socially constructed hierarchy of linguistic spheres that are synchronized with distinct geographical locations, gender, class, and profession. Mukul Sexena modifies diglossia into something he calls "critical diglossia," which suggests that diglossia is by no means a "natural state" of language but needs further inspection of the ideological, socio-cultural, economic and political dimensions of its origin. Sexena's critical engagement with diglossia exposes the internal tension that exists in this twofold linguistic structure in bilingualism or diglossia. ${ }^{4}$ Schaffner and Adab's idea of the emergence of hybrid texts through the act of translation is an intriguing one. I find these concepts of hybrid texts, bilingualism, and diglossia are particular productive for my exploration of the kan-wa diaglossia (kanwa nijū gengo $k \bar{o} z \bar{o}$ 漢和二重言語構造) in the Japanese writing system. To understand Yokoyama Yūta's narrative, one need to attune to the internal tension and dynamism when multiple languages reside in one single text, specifically focusing on Sino-Japanese hybrid articulations in the said text.

Sino-Japanese textual hybridity in Japan began as early as the inauguration of its writing system, as is evident in the use of the predecessor to Manyogana in the $5^{\text {th }}$ century. By employing a foreign orthographical system (Chinese characters) to represent the Japanese language, one may say that the majority of Japanese texts are rendered bilingual and hybrid in nature. In other words, this unique phonetic interface (even though Chinese characters are not phonetic symbols they are used for their sounds and not meanings) is what gives Japanese text its bilingual hybridity. This borrowing of Chinese characters to first represent a foreign phonetic system, and later, to represent their original semantic content, created a system of deciphering text that is called Kanbun kundoku 漢文訓読, a unique Japanese way of reading Chinese texts. This is in some ways "a translation system without translation." In this way, Japanese historically could access Chinese original texts and read them (almost in Chinese), with notes and verb endings in the kana

\footnotetext{
4 Saxena, Mukul. 2014. "Critical diglossia" and "Lifestyle Diglossia": Development and the Interaction between Multilingualism, Cultural Diversity and English." International Journal of the Sociology of Language 225 (2014): 91-112.
} 
phonetic notation.

According to Franco Fabbro, bilingual and multilingual conditions have been with us for a long time and over half of the world's population is bilingual. ${ }^{5} \mathrm{He}$ distinguishes three types of bilingualism, namely, compound ([fused bilingualism], when an individual learns two languages in the same environment and acquires one notion with two verbal expressions), coordinate ([separate bilingualism] when one acquires two languages in different contexts and uses them as separate and independent systems), and sub-coordinate (where one language dominates). The taxonomy is helpful in distinguishing the traditional Sino-Japanese texts, which perhaps more closely align with a compound bilingual experience, from Yokoyama's contemporary rendition of a Sino-Japanese text, which is more similar to a coordinate bilingual maneuvering.

\section{Bilingual Text in Practice: From Sōseki's / am a Cat to Yokoyama's / Become a Cat}

In the following I will use Yamada Yūta's novel I Become a Cat (『吾輩八猫二 ナル』, 2014) to illustrate the textual manifestation of a dual structure that is uniquely afforded to the Japanese language. The work is the debut novel of the young writer and immediately garnered critical attention due to its innovative experimental methodology and its spirited bilingual play on the dualistic structure embedded in Japanese. It was awarded the Gunzō New Writer Literary Award and was also nominated for the Akutagawa Award. Yamada received his Japanese teacher certificate and moved to China in 2005. As the title indicates, Yamada's work is only the latest of a long stream of works that have been influenced by or re-appropriate Natsume Sōseki's I Am A Cat. Hibi Yoshitaka, in his How Is Literary History being Re-Written (2016) provides one hundred and six titles of derivative texts that allude to Sōseki's masterpiece, a fact that speaks to the canonic status of both Sōseki and the popularity of the text. Yamada Yūta's referencing of $I \mathrm{Am} \mathrm{A}$ Cat takes its context out of Japan proper and transplants his narrative to the linguistic and literary border of China and Japan.

The narrative begins with a preface (jo), a frame story, in which a purported

5 Franco Fabbro, The Neurolinguistics of Bilingualism (East Sussex, UK: Psychology Press, 1999): 103, Francois Grosjean, Bilingual: Life and Reality (Cambridge, MA: Harvard University Press, 2010), xiv, 22. 
unnamed author who lives in China relates that a Chinese friend, Mr. Ma, asked him to recommend a Japanese novel that does not contain so many katakana because the graphic system of katakana reads like a “spell (呪文) or encryption(暗 号)"and this is the most difficult aspect for a non-Japanese to decipher. Without much hesitation, he recommends and lends the friend a copy of I Am A Cat. The said friend, after a few days brings the book back complaining about how old fashioned the language is and that the author Natsume's use of Chinese kanji was confusing. Motivated by Ma's predicament, the author decides to write a novel geared toward Chinese readers who are learning Japanese. The protagonist of the novel Kakeru (Junjun 駿駿 in Chinese) is a seventeen year old bi-racial high school student who lives in Shanghai and attends a Japanese high school. The protagonist remembers fondly how his Japanese father used to visit his mother and him every year from Japan and play catch with him. Now, however, the father had passed away and the original plan to attend university in Japan has become unachievable. Geographically, the story takes us from Shanghai to Suzhou, where the protagonist is to attend university, and finally to Tokyo, and finally the journey ends with a visit to a maid café at the mecca for the Otaku tribe, Akihabara. In the following, I will highlight two aspects of Yokoyama's textual experimentation: bilingual lexical innovation and textual hybridity.

\subsection{Lexical Innovation}

The text employs multiple inventive notational systems to simultaneously introduce and translate current Chinese lexical items to readers. The coinage can roughly be separated into three categories: First, lists of objects (appliances, places, fruits, proper names, automobiles, etc.) pop up throughout the text. This category is the most easily understood by both Chinese and Japanese readers since these terms do not deviate too much from their original meanings.

The second category is in fact reversing the function of katakana in designating foreign loanwords (gairaigo 外来語) by translating Western terms first into Japanese katakana representation, then finally Chinese translation. The triple translation process familiarizes the terms for Japanese readers.

The third category is more complex and creative. It take a strategy similar to 
the jukujikun 熟字訓, a system also refers to as a semantic loan (shakui hyōki借義表 記) that has a long history in Japan. Unlike the more conventional sound reading (onkun 音訓) where the reading is regularized and limited to one or several sets, this type of reading and representation of kanji does not align in a traditional way, but is rather connected through a seemingly random linkage of Chinese characters and Japanese pronunciation based on both languages. By doing this type of representation, Yokoyama created a system that parodies the macaronic language, a vernacular that playfully combines a language (mostly European languages) with Latin ending that sometimes also jestingly refers to as "dog Latin." Using this tactic, the text generates numerous bilingual puns through visuality.

\subsection{Textual Hybridity: text, meta text, and cross-generic texts}

With all his inventive play on transliterations, neologisms, and cross-translations, Yokoyama's bi-lingual enactment does not stop at the lexical level of mixed graphics; he further engages his reader with mixed visual texts, such as blending text and visuals and text and meta-text. The main text juxtaposes with photos of the twelve zodiac animals, which the narrator found in a park next to his home. The zodiac animals represent a cosmological view in absentia of the cat. These visual markers at times delineate the attributes of each animal in contrast with real cats that roam the park, which the protagonist plays with. He even names one he particularly likes "sensei," echoing again the good-natured mutual affection between the cat and the narrator Sensei in Sōseki's narrative. The copious notes imparting socio-political, cultural, and linguistic information (slang, newly coined words) to the Japanese reader reminds us of the excessive annotation of Tanaka Yasuo's popular novel Somehow Crystal (Nantonaku kurisutaru, 1980) which supplemented the thinly disguised product and life style endorsement narrative with 442 endnotes in a slim novel. Tanaka Yasuo's annotations focused mostly on luxury brand names, Euro-American popular music, and fashion and lifestyle trends pursued by urban youth during the bubble 80 's, forming a pedagogical handbook that spoke to domestic young Japanese readers of the time. Yokoyama's meta-text, on the other hand, functions as a cross-cultural guide that provides current socio-cultural context for the Japanese reader as the bare bones narrative focuses on the single narrative 
threat of the protagonist's journey to the popular culture of Japan, a subject more attuned to the interests of Chinese readers. This textual bi-focalism, aiming at two intended audiences, displays Yokoyama's literary ambition and his cross-cultural dexterity.

Besides the linguistic (bi-lingual) and formalistic (hybrid text) implementation, Yokoyama also employs multiple generic devices to further complicate the narrative. The text is peppered with haiku (which the protagonist and his fellow students compose in their Japanese language classes), J-Pop lyrics, passages from Chinese school textbooks, street signs, and the public announcements that are ubiquitous in China. Our protagonist Kakeru/Jun loves a good word game. He set up a Haiku Promotion Committee (俳句推進委員会) and even self-publishes a haiku magazine called 森規(a portmanteau coinage combining Masaoka Shiki 正岡子規, the poet who revolutionized modern haiku and the best friend of Sōseki who created the famous haiku magazine Hototogisu). However, not wanting to be kept in a box, Kakeru changes the term 俳句 into the self-mocking 琲句; ${ }^{6}$ and the essential poetic device for haiku, the seasonal word 季語 into Sino-word 華語 instead.

Seeing language as a game, Kakeru composes haiku and bi-lingual comic limericks, a puzzle that he put together with an electronic dictionary. For example, Kakeru composes a limerick modeled after the classical seven-character Qiyan 七言 poem where seemingly randomly chosen two, three, and four character Chinese compound words have their counterparts in three, four, and five syllable Japanese equivalents all ending with the syllable $\mathrm{Ra}$. Kakeru comments:

"This is not the typical classical seven-word poem that one sees in the nationally designated language art textbook in the PRC. No, it is not even a poem at all. The words are free radicals floating like weeds. You can say it is closer to a game of 接龍, a double-tier puzzle. Take a piece and another piece in another layer moves in response like its shadow. Nevertheless, the shapes of pieces from the two layers are different. So even if one piece fit nicely into one tier, it does not guarantee that the corresponding pieces in another layer can fit snuggly into it." (pp.37-38)

The description of this bi-lingual limerick seems to be the perfect metaphor for

6 The character 俳 (pronounced [hai]) does not exist in Chinese. Here Yokoyama replaces it with the character 啡 (pronounced [fei] taken from coffee 咖啡) to play on the similarity of the sound symbol 非but also to create the pun "feiku/fake" to indicate his is a imitative version of Japanese haiku. 
describing the figuratively literal symbiotic coexistence yet functioning distinctive relationship between the Chinese and Japanese languages. The two languages share semiotic codes and have a long intertwining historical and cultural relationship that can be described as an object and its "shadow." Yet, "what works for one layer of system does not necessarily work for another" also suggests that the two systems complement/accommodate each other but remain distinct.

\section{Conclusion}

Kakeru remarks on the poverty of one-layered orthographic systems such as Chinese, English, and Arab, which do not possess the aesthetic pleasure of mixed transcriptions. He further finds stability in an orthography that balances kanji and hiragana: "though not particularly efficient (as a writing system), they complement each other and each has its own beauty”あまり経済的とは思えないが、双方が補完し 合っている様子はそれなりにうつくしい (pp.38-39) Kakeru also characterizes katakana and foreign loan words, which now occupy about $30 \%$ of the Japanese lexicon (the number in 1994, an increase from less than $10 \%$ in 1956) as "detestable" and "confusing" and hopes for a day when the interference of US/English can be eliminated and the "strategic mutually beneficial, beautifully harmonized relationship between kanji and hiragana" can be restored. (p.39)

The protagonist Kakeru has devoted much time to contemplating the many issues of Sino-Japanese transcription, conversion, transmutation and intercultural communication, and despite his mixed blood heritage and his many years of Japanese education (in Shanghai), his journey to Japan and to Akihabara specifically brings an unexpected cultural shock. As he steps into the maid café, the maids speak in "cat language" 猫語 (one of the moe 萌え elements in Otaku culture) that is totally incomprehensible to Kakeru as his world of bi-logocentric order deteriorates into a phonocentric world of (in Kakeru's mind) random and arbitrary utterances.

If the history of modern Japan is a process of abandoning a Sino-centric East Asian worldview for a Euro-centric modernity, Yokoyama's attempt to expunge katakana-go indicates a possible postcolonial turn, reorienting the focus toward the

\footnotetext{
7 See “日本語の中の外来語と外国語——新聞, テレビ, j-pop-”

http://www.ninjal.ac.jp/archives/event_past/forum/31/haihu_31.pdf

https://www.ninjal.ac.jp/archives/event_past/forum/30/kiroku_30.pdf
} 
East Asian cultural sphere.

The author Yokoyama Yūta set out to create a text that combines translation, transliteration, and bilingual practice in order to relocate Sōseki's canonical work out of the Meiji domestic environment and turn it into a bi-cultural global text. In modern Japanese literature, writers of previous generations who engaged in their writings with China or kanbun, by which I mean Meiji writers such as Kōda Rohan, Mori Ōgai, Sōseki and many Meiji bunjin literati, whose knowledge of China and the Chinese language and literature were more culturally mediated (through the kanbun tradition), enjoyed a holistic acculturation through accumulated historical knowledge. Yokoyama's engagement with China, on the other hand, designates a deliberate act of border crossing that was facilitated by transnational movements (both geographical and cultural) that have become common in a globalized world. Instead of learning historically mediated knowledge of China, Yokoyama quit Kagoshima University after his freshman-year and moved to China at age 23 (and since has been teaching Japanese and learning Chinese literature in China). His first hand experience and in-situ expertise on contemporary Chinese youth's language use and cultural consumption (i.e., slangs, Japanese pop culture, game culture, etc.) make him a unique voice in the new generation of Japanese writers. Derrida proposed "a general strategy of deconstruction" in saying "to deconstruct the opposition is above all, at a particular moment, to reverse the hierarchy." (Positions, pp.56-57) Yokoyama's bold experiment through code-switching in this sense can be seen as his mischievous attempt to subvert the hierarchy of the trinity of hiragana, katakana, and kanji.

\footnotetext{
参考文献

鈴木義里 (2002)『論争·英語が公用語になる日』, 東京：中央公論社. Yoshisato, Suzuki(2002) Ronsou·Eigo ga Kongyongo ni Naru Hi. Tokyo : ChuoKoronsha.

Christina Schäffner and Beverly Adab (2001) The Idea of the Hybrid Text in Translation : Contact as Conflict. Across Languange and Cultures 2. Akadémiai Kiadó, 167-180.

Franco Fabbro (1999) The Neurolinguistics of Bilingualism. East Sussex, UK : Psychology Press, 103.

Francois Grosjean (2010) Bilingual- Life and Reality : Cambridge, MA : Harvard University Press, xiv. 22.

Lydia H. Liu(1995) Translingual Practice Literature. National Culture, and Translated Modernity —China, 19001937. California : Stanford University Press, 1-42.

Saxena. Mukul (2014) Critical diglossia and lifestyle diglossia: Development and the Interaction between Multilingualism. Cultural Diversityand English. International Journal of the Sociology of Language225, 91-112.
} 
福田亮·伊藤雅光·塩田雄大 (2007年2月24日) 日本語の中の外来語と外国語 一新聞，㮅誌，テレビ一，国立国 語研究所. 2018.4.30. Ryo, Fukuda·Masamitsu, Itou·Takehiro Shioda(2007.2.24) Nihongo no Naka no Gairaigo to Gaikokugo-Shimbun, Zasshi. Terebi. Kokutitu Kokugo Kenkyuzyo. Access date : 2018.4.30 〈https://umw.ninjal.ac.jp/archives/event_past/.../30/haihu_30.pdf, https://wnw.ninjal.ac.jp/archives/event_past /.../31/haihu_31.pdf>

\section{阮斐娜 Faye Yuan KLEEMAN}

（アメリカ）コロラド大学アジア言語文化学科教授。日中比較文学、日本近現代文学、植民地文 学文化、大衆文化論。『大日本帝国のクレオール植民地台湾の日本語文学』(東京：慶應大学出版 会. 2007)、『In Transit: Formation of an East Asian Cultural Sphere』(University of Hawaii, 2014)な よ゙。 